\title{
植物的发育: 从细胞到个体
}

\author{
罗林杰, 曾健, 田朝霞, 赵忠 ${ }^{*}$ \\ 中国科学技术大学生命科学学院, 合肥 230027 \\ * 联系人, E-mail: zhzhao@ustc.edu.cn
}

2016-08-22 收稿, 2016-09-17 修回, 2016-09-18 接受, 2016-10-12 网络版发表

国家重大科学研究计划(2013CB967300)和国家自然科学基金(31570273, 31270325)资助

\begin{abstract}
摘要随着分子生物学研究手段的丰富, 植物发育生物学也从宏观的植物形态观察走向了微观的细胞和基因水 平的研究. 植物本身有着显著不同于动物的胚后发育特征，这种发育模式赋予了植物极其灵活的发育可塑性以应 对不同的生长环境. 在长期进化过程中, 植物正是通过持续的调整发育来适应外界环境变化, 造就了植物界末富 的多样性. 本文以植物千细胞的功能和调控为核心，阐述了干细胞调控植物胚后发育的模式以及植物内源激素对 干细胞和植物发育调控的贡献，讨论了内源的遗传信息和外部的环境因素在植物发育过程中的整合，以及这些因 素如何调控农作物的器官和形态发育，继而影响到作物的产量.
\end{abstract}

关键词发育的可塑性, 干细胞，激素，模式建成，产量性状

不同的生存环境造就了大千世界植物的多样性, 自然界中既有株高仅有 $10 \mathrm{~cm}$ 左右的北极柳树，也有 高达 $100 \mathrm{~m}$ 以上的参天大树一一红杉. 这种植物形态 的多样性是与其对环境的适应息息相关的, 因此植 物发育调控的核心是如何适应环境的变化, 以期在 长期的种群进化过程中获得生存的优势. 所以, 在植 物个体发育过程中器官的模式建成、种类、数目和大 小都受到了精细的调控以适应不断变化的外界环境.

\section{1 植物生长发育的可塑性}

绝大部分陆生植物的个体在生长过程中都是不 可移动的、采取了固着的生活方式. 同时植物细胞壁 的刚性结构也限制了绝大部分细胞的自由移动. 因 此, 植物在进化过程中发展演化出了一套不同于动 物的更为灵活的发育模式.

高等生物的生长发育在时间顺序上可以分为胚 胎发育和胚后发育. 千姿百态的动植物个体无一例 外都是从单细胞受精卵开始, 经过细胞的分裂、分化
和组织器官的建成而完成其生长发育的整个过程, 因此胚胎发育是高等生物有性生活史的重要起始环 节。植物的胚胎发育，从受精卵开始经历了合子激 活、极性建立和器官分化等过程, 最后形成具有茎尖 和根尖生长点、子叶以及下肧轴 4 个基本结构的胚 胎 ${ }^{[1]}$. 其早期以不对称细胞分裂建立顶-基和辐射极 性发育轴向为特点. 研究表明, 动、植物胚胎发生的 早期过程均有着类似的特征：其合子的激活都会伴 随着一个胞内的钙离子信号通路的活化 ${ }^{[2,3]}$; 合子的 第一次分裂均为不对称性分裂，并由此建立了整个 胚胎发育的极性轴向. 植物胚胎发育的中期, 器官原 基开始产生，其扩张到晚期形成成熟的胚胎 ${ }^{[4]}$.

但是，与动物不同，植物在胚胎发育过程中只产 生少数的组织和器官原基, 例如子叶、下肧轴、茎尖 和初生根. 而动物在胚胎发育完成后, 所有的组织器 官原基均已建成，其中包括生殖细胞，一般情况下不 会在胚后发育过程中产生新的器官. 植物绝大部分 的器官, 包括根系、茎、真叶、花和果实, 均是在胚 
后发育过程中由顶端分生组织不断分化所形成的新 器官. 这种独特的胚后发育模式赋予了植物极强的 发育可塑性以适应生长环境的快速变化. 因此, 高等 植物的个体发育主要是胚后器官的发生和形态建成 的过程.

在植物胚后发育过程中, 所有新生的器官均来 自顶端分生组织的分裂和分化, 地上部分所有的器 官(除了子叶与肧轴外)来自于茎顶端分生组织(shoot apical meristem, SAM), 而地下部分的根系则来自于 根顶端分生组织(root apical meristem, RAM) ${ }^{[4]}$. 植物 的肧后发育受到了各种外界环境因素和内在遗传因 素的影响, 所以茎和根顶端分生组织的精细调控, 特 别是内在发育信号对外在环境信号的整合对于高等 植物正常的生长发育具有至关重要的作用. 这种发 育的可塑性不仅影响了顶端分生组织对其细胞分裂 分化和器官发生的调控, 也决定了不同组织器官的 特异性与多细胞植物个体的多样性.

\section{2 干细胞是植物发育过程调控的核心}

在植物的发育过程中, 顶端分生组织可以终生 维持其分裂和分化能力, 这是由于顶端分生组织中 存在着一类具有自我更新能力和多种分化能力的特 殊细胞类群-植物干细胞. 目前认为植物存在 3 个主 要的干细胞群: 茎干细胞位于茎顶端分生组织中, 是 植物胚后地上所有器官的来源; 根干细胞位于根顶 端分生组织中, 是植物根系的来源. 形成层干细胞位 于形成层, 参与维管束的形成和分化.

干细胞是植物体内所有细胞、组织和器官的最初 来源, 其在植物生活史中的重要性不言而喻. 植物之 所以能够适应胚后生长的复杂环境、完成生长发育过 程, 是与干细胞能快速响应环境变化信号, 并直接参 与调控植物发育的进程有着密切的关系.

以位于拟南芥茎顶端分生组织中的茎干细胞为 例, 拟南芥所有地上部分的器官 (除子叶和下肧轴外) 都是来自于茎干细胞的分裂和分化. 为了维持干细 胞及保障其对发育的调控, 茎顶端分生组织形成了 一个精密分区的结构和多信号整合的调控机制, 这 为干细胞的维持和分化提供了重要的基础. 干细胞 位于茎顶端分生组织的最中央 (中央区), 大约由 15 30个细胞组成. 两侧的周边区细胞来自于干细胞 的分裂, 为以后侧生器官的分化提供起始细胞. 茎顶 端分生组织最外围的区域是已经起始分化的原基区,
随着发育的进行，会最终形成成熟的叶或花. 干细胞 的正下方区域为组织中心, 为干细胞提供重要的微 环境信号, 是维持干细胞的功能所必需的 ${ }^{[5]}$.

尽管干细胞在组织形态上与顶端分生组织中的 其他分化细胞没有明显的区分, 但在生物学功能上 有着显著的差异. 第一, 干细胞存在特异表达的基 因. 目前 $C L V 3$ 作为编码一个可分泌多肽的基因已经 被大家广泛认可为干细胞的标记基因. 实际上, 干细 胞在茎顶端分生组织中区域最初就是通过 $C L V 3$ 基因 的表达范围来划分出来的 ${ }^{[6]}$. 除此之外, 近年来还有 多个基因也被发现在干细胞中特异的表达, 例如 AIL7, LOG7, PUM10等 ${ }^{[7]}$. 第二, 干细胞具有自我更 新的能力. 植物不仅可以维持自身的干细胞的属性, 还可以维持干细胞数目的稳定. 组织中心特异表达 的基因WUS为维持干细胞的属性和数目提供了重要 的信号 ${ }^{[8]}$. WUS蛋白在组织中心表达, 移动到干细胞 区域维持了干细胞的属性, 并激活干细胞标记基因 $C L V 3^{[9,10]}$. $C L V 3$ 作为一个多肽反过来可以通过 $C L V 1$, $C L V 2, C R N$ 等膜受体介导的信号通路抑制WUS表达 的区域, 从而建立了一个精密的负反馈循环, 维持了 干细胞数目的稳定性 ${ }^{[115]}$. 第三, 植物干细胞维持 低的分裂频率. 干细胞分裂的两个子细胞中一个继 续维持着干细胞的状态, 而另一个会进人周边区作 为起始分化的原初细胞 ${ }^{[5,16]}$. 与已分化的细胞相比, 干细胞的分裂频率较慢. 例如, 拟南芥顶端分生组织 中, 中央区干细胞的有丝分裂指数仅为周边区分化 细胞的一半 ${ }^{[16,17]}$. 第四, 干细胞具有分化的多能性. 在顶-基轴向上可以分化为茎的基本组织, 在辐射轴 向上可以分化为叶或花器官. 茎顶端分生组织可被 分为三层细胞，位于第一层的干细胞可以分化为表 皮细胞和表皮毛细胞, 位于第二层的干细胞会分化 为叶片和其他器官的中间组织, 位于第三层的干细 胞会分化为维管束细胞 ${ }^{[18]}$.

由此可见, 干细胞作为所有分化细胞的来源, 其 功能的维持和持续分化是调控植物生长发育最重要 的机制. 如果干细胞的调控出现缺陷, 则会严重影响 植物的生长发育过程. 例如, 组织中心特异表达的基 因WUS突变后, 茎干细胞不能被维持, 从而产生了 顶端分生组织缺失、植物生长发育停止的严重表型 ${ }^{[8]}$. 反之在 $\operatorname{lv} 3$ 突变体中, 由于解除了对WUS的表达的抑 制, WUS 表达范围扩大，从而促进了干细胞的积累， 其侧生器官的数目也明显增加 ${ }^{[6]}$. 
虽然干细胞的维持非常重要, 但其最终目的是 为分化提供足够的起始细胞. 干细胞分裂后, 其部分 子细胞进人其两侧的周边区走向分化过程. 周边区 细胞分裂的频率较高, 大量与分化相关的基因在这 里表达. 例如在生长素促进干细胞分化的过程中, 其 应答因子 $(A R F 5 / M P)$ 在整个周边区都有强烈的表达. 当 $M P$ 突变后, 侧生花原基的分化和发育过程全部被 阻断, 花序分生组织出现了针状的表型 ${ }^{[19,20]}$.

不仅是在茎的顶端, 在根顶端中也存在着一套 精密的机制控制根干细胞的维持和分化. 在根顶端 分生组织中, WUS 的同源基因WOX5 在静止中心表达, 维持根干细胞的功能 ${ }^{[21]}$. 在结构上, 根干细胞辐射 状围绕静止中心, 并向周围分化形成根冠细胞、皮层 细胞、中柱鞘细胞、中柱细胞. 与茎顶端分生组织类 似, 在根顶端分生组织中也存在着与CLV3类似的多 肽类激素. 其中, CLE40通过受体激酶ACR4来抑制 WOX5 的表达, 进而调控静止中心的维持 ${ }^{[22]}$. 除此之 外转录因子 $S H R$ 和 $S C R$ 也对根干细胞的维持起着重 要的作用. $S H R$ 特异的在中柱表达, 但其蛋白会移动 到内皮层细胞和静止中心来维持干细胞的稳定 ${ }^{[23,24]}$. 而 $S C R$ 则表达在内皮层细胞和静止中心, 作为转录因 子激活下游基因的表达来维持根干细胞的功能 ${ }^{[25,26]}$.

此外, 干细胞也存在于维管组织的形成层中, 形 成层干细胞的不断分裂分化形成了木质部和韧皮部. 无论是在维管组织的初生生长还是次生生长, 形成 层干细胞都起着关键的作用. 例如在初生生长中, 生 长素激活了其转录因子 $M P, M P$ 则通过正调控 $A T H B 8$ 的转录促进了 PINI的表达, 由此形成了一个正反馈 循环调控初生生长 ${ }^{[27 ~ 29]}$. 次生生长过程, 除了 $R E V$ 可 能参与了木质部的发育外, 其调控机制目前了解较 少 ${ }^{[30]}$. 与茎和根干细胞类似, 在维管组织中也存在 着多肽类激素, 调控形成层干细胞的维持和分化 ${ }^{[31]}$. 其中, CLE41多肽与其受体激酶(PXY)的互作调控了 维管组织的分化 ${ }^{[32]}$, 并维持了 WOX4 的表达 ${ }^{[33,34]}$. WOX4则对形成层干细胞的维持起着至关重要的作 用, 当WOX4突变后, 维管组织的次生生长被严重抑 制 ${ }^{[33,35]}$.

不仅是在模式植物拟南芥, 从低等的苔藓植物、 石松门植物, 到裸子植物和被子植物, 干细胞在个体 发育过程中都起到了重要的作用, 其调控机制也具有 一定的保守性. 其中, WOX基因家族的功能在植物进 化中的保守, 印证了干细胞调控机制起源的古老性和
在进化过程中的保守性 ${ }^{[36]}$, 例如 WOX的同源基因甚至 存在于绿藻中. 在苔藓植物小立碗藓中, $P p W O X 13 \mathrm{~L}$ (WOX13同源基因)对干细胞的起始和维持有着重要 的调控作用 ${ }^{[37]}$. 在石松门植物中也存在着 8 个 $W O X$ 同 源基因, 其器官的再生过程中也涉及到 $W O X$ 基因的 表达 ${ }^{[38]}$.

\section{3 激素调控植物干细胞的维持和分化过程}

在植物干细胞的维持和分化过程中, 生长素和 细胞分裂素是两个起重要调控作用的植物激素. 目 前, 细胞分裂素参与调控干细胞的维持, 生长素参与 调控器官原基的起始的观点已经被广泛认可.

细胞分裂素对维持干细胞的重要调控基因 $W U S$ 的功能起到了非常重要的作用. 作为细胞分裂素下 游的A type-ARR (ARABIDOPSIS RESPONSE REGU$L A T O R)$, 例如 $A R R 5, A R R 6, A R R 7$ 和 $A R R 15$, 被首先 发现是 $W U S$ 直接负调控的下游基因 ${ }^{[39]}$. 过量表达持 续磷酸化激活的 $A R R 7$, 出现类似 $w u s$ 突变体的表型. A type-ARR作为细胞分裂素的负调控因子, WUS对其 的抑制意味着WUS维持干细胞的功能很可能依赖于 细胞分裂素的信号转导途径. 同时, WUS基因的转录 可以被体外高浓度的细胞分裂素所诱导 ${ }^{[40]}$. 当负责 细胞分裂素降解的细胞分裂素氧化酶(CYTOKININ OXIDASES, CKXS) 突变后, 细胞分裂素的积累造成 $W U S$ 表达的明显增加 ${ }^{[41]}$. 细胞分裂素感应元件 $(T C S:: G F P)$ 的检测也表明细胞分裂素富集在 WUS 表 达的组织中心区域 ${ }^{[40,42]}$. 相反当细胞分裂素合成酶 $L O G$ 突变后, 呈现出了顶端分生组织和干细胞维持 的缺陷, 表明细胞分裂素无论是合成还是信号转导 都在干细胞维持的过程中起到了重要的作用 ${ }^{[43]}$.

生长素则在干细胞分化和原基的起始过程中起 着非常重要的作用. 人工合成的生长素感应元件 (DR $5: \because G F P$ 和D II : VENUS) 在顶端分生组织中的分布 表明 ${ }^{[44]}$, 生长素合成后被运输到周边区的原基起始 区，形成高的浓度梯度，通过信号转导激活下游基因 表达, 最终开启原基的起始和发育 ${ }^{[45,46]}$. YUC基因家 族主要负责顶端分生组织中生长素的合成, 在 $y u c 1$, 2, 4, 6 四突变体中原基不能起始而形成针状的表 型 ${ }^{[47,48]}$. 此外, 在生长素极性运输缺陷突变体pin1, pid中也会产生类似的针状的表型 ${ }^{[20]}$. 除了生长素的 合成和运输外, 破坏生长素的信号转导通路也会产 生针状表型。近期的研究发现，生长素应答因子 
(ARF5/MP) 可以通过正调控其下游基因 $L F Y, A N T$, AIL6的表达来调控花器官的发育 ${ }^{[49]}$. 由此可见, 生 长素的合成、运输和信号转导对干细胞的分化和原基 的起始都是必不可少的. 这些发现建立了我们对生 长素调控器官发生和发育分子机制的基本认识.

尽管生长素在干细胞分化过程中起到了重要的 作用, 近几年的研究也证实了生长素同时可以被运 输到干细胞区域, 因此生长素在干细胞稳态调控中 也起着重要的作用. 20 世纪 50 年代, 通过体外组织培 养和植株再生的研究, 人们发现在体外生长素和细 胞分裂素可以协同诱导植物干细胞的形成 ${ }^{[50]}$, 但其 分子机制长期不为人所知. 在体内生长素可以通过 顶端分生组织 L1层细胞运输到干细胞中, 形成L1层 向下的浓度梯度. 而细胞分裂素则在组织中心富集, 形成与生长素相反的逆向浓度梯度, 因此干细胞中 存在着这两种激素的动态平衡. 我们前期的研究结 果表明, 作为细胞分裂素的信号通路的负控调因子, $A R R 7$ 和 $A R R 15$ 可以被生长素信号转导途径中的重要 生长素应答因子 MP所直接抑制, 参与干细胞内生长 素和细胞分裂素动态平衡的维持. 另一方面, $A R R 7$ 和ARR15也参与了对干细胞标记基因 $C L V 3$ 表达的正 调控. 也就是说, $A R R 7$ 和 $A R R 15$ 能同时整合生长素和 细胞分裂素的信号, 继而通过调控WUS/CLV3的负 反馈循环来维持干细胞的稳态 ${ }^{[20]}$.

\section{4 外界环境对植物生长和发育的影响}

植物的生长发育不仅依赖于其自身的遗传信息, 外界环境也会传递各种信号来影响其生长和发育过 程. 例如光照和温度可以通过光周期和春化途径来 影响植物开花的时间; 生长逆境会诱导植物提前开 花, 加速世代交替的进程; 土壤的干旱环境和养分的 不均匀分布会影响植物根的形态建成等等 ${ }^{[51]}$.

开花是植物进人生殖生长的重要标志, 其调控 不仅依赖于内在的自主开花途径和赤霉素途径, 外 界的光周期和春化途径也起着至关重要的作用. 光 周期影响开花是植物根据日照长短, 来调节自身开 花时间的生理现象. 对于长日照植物拟南芥而言, 长 日照促进开花, 短日照抑制开花. 当日照时间发生改 变时, 植物接受日长/夜长信号并通过基因调控网络 将信号传递下去, 最终达到控制花原基起始和发育 的目的. 光敏色素是光周期反应中最主要的光受体, 其激活后将光信号传递给 $C O$, 后者通过 $F T$ 和 $S O C 1$
激活花原基的属性基因 $A P 1$ 来诱导花原基的起 始 ${ }^{[52 ~ 57]}$. 低温处理(春化作用)也是促进植物开花的 一个重要环境因素. 春化作用通过表观遗传调控，抑 制FLC的表达，从而解除了 FLC 对 FT和 SOC 1 的抑制, 促进了植物的开花 ${ }^{[58-62]}$.

植物的生长发育过程往往还会受到不利环境因 素的胁迫, 例如高温、干旱、盐胁迫以及氧化胁迫等 都会影响植物的生长. 动物具有可移动性和避逆性, 而植物则需要通过调整生长发育过程来适应逆境的 胁迫. 逆境信号的响应与植物发育过程的调控是紧 密相连的, 如 SCARECROW可以响应逆境信号从而调 控了拟南芥根系的生长发育过程 ${ }^{[63]}$. 在水稻中 $O S O P R 1$ 可以响应包括机械损伤、氧化胁迫、重金属 等多种逆境信号, 从而影响水稻生长发育的过程 ${ }^{[64]}$.

在进化的过程中, 植物演化出了一套完整的机 制适应所处的不良环境. 尽管植物对不同环境胁迫 因素响应的机制具有多样性和独特性，但这些机制 都是以基因调控的信号网络为基础来影响植物的发 育. 研究这些调控机制对于我们改良农作物和理解 植物的多样性具有重要的意义. 在玉米中通过转基 因增加乙烯的合成, 可以极大地改善玉米在干旱环 境下的生长发育状态, 并提高玉米的产量 ${ }^{[65]}$. 因此 利用和改变植物发育对环境的响应, 可以有效地 提高作物对不良环境的适应性，通过调控作物的生 长发育来增加生物量, 有助于提高和稳定作物的 产量.

在自然界中, 植物的生长以及器官和形态建成, 不仅依赖于自身的遗传调控同时还受到外界环境因 素的影响, 最终造成了形态和大小各异的各种植物. 尽管红杉高达百米，而北极柳株高仅为十多厘米，二 者都具有类似的结构和器官, 包括根、茎、叶、花和 果实. 这些器官均是来自于干细胞的分化, 但是在长 期的进化过程中植物不断地通过调整发育来适应所 处的外界环境, 最终造成了植物在大千世界的丰富 的多样性.

\section{5 植物生长发育的调控与农作物的产量}

全世界的主要粮食作物多来自于单子叶植物, 如水稻、小麦、玉米等. 水稻的发育已经作为单子叶 模式植物被广泛研究. 禾谷类作物的产量性状与其 发育的调控密切相关. 水稻的产量主要是由有效分 罯数、穗粒数和千粒重 3 个指标决定的. 
分藥是禾本科植物所特有的一种分枝现象, 主 要产生在主茎基部接近地面处, 一旦分繤芽开始生 长就会形成一个完整的侧生枝条(分藥). 主茎远离基 部的叶腋处也产生芽, 但是这种新生芽会一直处于 休眠状态不会生长 ${ }^{[66]}$. 分临芽原基(侧芽原基)的起始 涉及到干细胞在叶腋处的诱导和维持. 水稻的分榄 是多基因控制的数量性状, 其中一个最重要的基因 是MOC1. 作为转录因子, $\mathrm{MOC} 1$ 属于植物所特有的 GRAS蛋白家族的成员. mocl突变体导致分藥缺失的 表型, 参与侧生分生组织起始、建立和维持的关键基 因 $O S H 1$, 以及控制侧芽伸长的 $O s T B 1$ 在叶腋中的表 达都受到了影响 ${ }^{[67]}$.

多种植物激素也广泛地参与了分葟的起始和发 育的调控. 顶端优势是生长素调控侧芽发育的一个 最著名的例子, 在顶端合成的生长素运输到侧芽处 积累, 抑制了侧芽的生长. 独脚金内酯是近年来新发 现的控制着水稻分菜和侧芽发育的另外一类重要的 植物激素. 独脚金内酯和其受体D14结合后与 D3、 D53形成复合体, 并利用26S蛋白酶体将D53降解, 从 而开启了下游基因的转录激活, 调控分蓝的数目 ${ }^{[68]}$. 在水稻育苗过程中, 促使分菜尽早发生可以达到增 加有效分藥的目的. 研究水稻分菜的发育机制, 将有 助于我们提高粮食作物的产量.

穗粒数是另外一个重要的形成水稻产量的主要 因素. 水稻穗粒数是由一次、二次枝梗的数目以及枝 梗上花的数目所决定的. 在水稻的发育过程中, 细胞 分裂素信号途径广泛地参与了枝梗原基和花原基的 发育及数目的决定. 例如, Gnla 是水稻中最早鉴定的 与产量性状相关的重要主效基因, Gn1a编码一个水 稻细胞分裂素氧化酶 $O s C K X 2^{[69]}$. 在 $O s C K X 2$ 缺失的 水稻品种中, 花序顶端分生组织中细胞分裂素的浓 度积累较高, 枝梗数目及小花的数目增加 $20 \%$ 以上,
从而促进了产量的提高. 通过转基因降低水稻 $O s C K X 2$ 的表达能够有效地增加穗粒数, 而增加 $O s C K X 2$ 的表达则降低穗粒数目 ${ }^{[69]}$. 因此, 细胞分裂 素的代谢是参与水稻产量性状形成的重要因子. 另 一方面, 细胞分裂素的合成也影响到了水稻穗粒的 数目. $\operatorname{LOG}$ (Lonely Guy) 基因是水稻茎顶端分生组织 中细胞分裂素合成最后一步的关键酶, 催化细胞分 裂素由无活性的前体转变成活性形式. 在 $\log$ 突变体 中, 顶端分生组织活性细胞分裂素的浓度降低, 整个 茎顶端分生组织变小, 一次枝梗、二次枝梗和小花的 数目则大幅度减少 ${ }^{[43]}$. OsCKX2 正调控因子 $D S T$ (Drough and Salt Tolerance)的突变同样导致了分生 组织细胞分裂素的积累、枝梗数目和穗粒数的增 加 ${ }^{[70]}$. 上述的研究表明, 细胞分裂素调控水稻顶端 分生组织(包括一次枝梗原基、二次枝梗原基和花原 基)的活性, 决定了水稻的穗粒数, 控制了水稻的产 量性状. 但是, 细胞分裂素控制穗粒数目这一重要产 量性状的基因网络及其作用的分子机制仍然不清楚.

同其他植物一样，外界环境因素同样会影响到 水稻的生长发育, 从而影响到水稻的产量. 土壤中充 足的 N, P, K 和微量元素可以促进分薯的发生. 在这 些元素中尤其是 $N$ 起着主导的作用. 水稻在分蓝时吸 收利用的 $\mathrm{N}$ 主要是铵态氮, 所以在分蓝期时适量施加 氮肥可以增加分菜. 另外分菜时期的水温也会影响 到分蓝, $30 \sim 32^{\circ} \mathrm{C}$ 水温是分藥的最佳水温, 过高或者 过低都会不利于分临. 除此之外, 光照、水分等环境 因素都会影响到分葟的产生 ${ }^{[71]}$.

随着植物生长发育过程中越来越多的基因及其 生物学功能的揭示, 以及植物发育对外界环境响应 机制的深人研究, 我们对植物如何调控生长这一科 学问题的理解必将从现象走向背后的机制, 并将其 运用到生产生活中以造福人类.

\section{参考文献}

1 Capron A, Chatfield S, Provart N, et al. Embryogenesis: Pattern formation from a single cell. Arabidopsis Book, 2009, 7: e0126

2 Miyazaki S, Ito M. Calcium signals for egg activation in mammals. J Pharmacol Sci, 2006, 100: 545-552

3 Digonnet C, Aldon D, Leduc N, et al. First evidence of a calcium transient in flowering plants at fertilization. Development, 1997, 124: $2867-2874$

4 W. D J G. Stem cells that make stems. Nature, 2002, 415: 751-754

5 Sablowski R. The dynamic plant stem cell niches. Curr Opin Plant Biol, 2007, 10: 639-644

6 Fletcher J C, Brand U, Running M P, et al. Signaling of cell fate decisions by CLAVATA3 in Arabidopsis shoot meristems. Science, 1999, 283: 1911-1914 
7 Yadav R K, Girke T, Pasala S, et al. Gene expression map of the Arabidopsis shoot apical meristem stem cell niche. Proc Natl Acad Sci USA, 2009, 106: 4941-4946

8 Laux T, Mayer K F X, Berger J, et al. The WUSCHEL gene is required for shoot and floral meristem integrity in Arabidopsis. Development, 1996, 122: 87-96

9 Daum G, Medzihradszky A, Suzaki T, et al. A mechanistic framework for noncell autonomous stem cell induction in Arabidopsis. Proc Natl Acad Sci USA, 2014, 111: 14619-14624

10 Yadav R K, Perales M, Gruel J, et al. WUSCHEL protein movement mediates stem cell homeostasis in the Arabidopsis shoot apex. Genes Dev, 2011, 25: 2025-2030

11 Brand U, Fletcher J C, Hobe M, et al. Dependence of stem cell fate in Arabidopsis on a feedback loop regulated by CLV3 activity. Science, 2000, 289: 617-619

12 Clark S E, Williams R W, Meyerowitz E M. The CLAVATA1 gene encodes a putative receptor kinase that controls shoot and floral meristem size in Arabidopsis. Cell, 1997, 89: 575-585

13 Muller R, Bleckmann A, Simon R. The receptor kinase CORYNE of Arabidopsis transmits the stem cell-limiting signal CLAVATA3 independently of CLAVATA1. Plant Cell, 2008, 20: 934-946

14 Ogawa M, Shinohara H, Sakagami Y, et al. Arabidopsis CLV3 peptide directly binds CLV1 ectodomain. Science, 2008, 319 : 294

15 Ohyama K, Shinohara H, Ogawa-Ohnishi M, et al. A glycopeptide regulating stem cell fate in Arabidopsis thaliana. Nat Chem Biol, 2009 5: $578-580$

16 Laufs P, Grandjean O, Jonak C, et al. Cellular parameters of the shoot apical meristem in Arabidopsis. Plant Cell, 1998, 10: 1375-1390

17 Jacqmard A, Gadisseur I, Bernier G. Cell division and morphological changes in the shoot apex of Arabidopsis thaliana during flora transition. Ann Bot, 2003, 91: 571-576

18 Meyerowitz E M. Genetic control of cell division patterns in developing plants. Cell, 1997, 88: 299-308

19 Przemeck G K H, Mattsson J, Hardtke C S, et al. Studies on the role of the Arabidopsis gene MONOPTEROS in vascular development and plant cell axialization. Planta, 1996, 200: 229-237

20 Zhao Z, Andersen S U, Ljung K, et al. Hormonal control of the shoot stem-cell niche. Nature, 2010, 465: 1089-1092

21 Sarkar A K, Luijten M, Miyashima S, et al. Conserved factors regulate signalling in Arabidopsis thaliana shoot and root stem cell organizers. Nature, 2007, 446: 811-814

22 Stahl Y, Wink R H, Ingram G C, et al. A signaling module controlling the stem cell niche in Arabidopsis root meristems. Curr Biol, 2009, 19: 909-914

23 Helariutta Y, Fukaki H, Wysocka-Diller J, et al. The SHORT-ROOT gene controls radial patterning of the Arabidopsis root through radial signaling. Cell, 2000, 101: 555-567

24 Cui H, Levesque M P, Vernoux T, et al. An evolutionarily conserved mechanism delimiting SHR movement defines a single layer of endodermis in plants. Science, 2007, 316: 421-425

25 Di Laurenzio L, Wysocka-Diller J, Malamy J E, et al. The SCARECROW gene regulates an asymmetric cell division that is essential for generating the radial organization of the Arabidopsis root. Cell, 1996, 86: 423-433

26 Sabatini S, Heidstra R, Wildwater M, et al. SCARECROW is involved in positioning the stem cell niche in the Arabidopsis root meristem. Genes Dev, 2003, 17: 354-358

27 Reinhardt D. Vascular patterning: More than just auxin? Curr Biol, 2003, 13: R485-R487

28 Scarpella E, Marcos D, Friml J, et al. Control of leaf vascular patterning by polar auxin transport. Genes Dev, 2006, 20: 1015-1027

29 Donner T J, Sherr I, Scarpella E. Regulation of preprocambial cell state acquisition by auxin signaling in Arabidopsis leaves. Development, 2009, 136: 3235-3246

30 Robischon M, Du J A, Miura E, et al. The populus Class III HD ZIP, popREVOLUTA, influences cambium initiation and patterning of woody stems. Plant Physiol, 2011, 155: 1214-1225

31 Hirakawa Y, Shinohara H, Kondo Y, et al. Non-cell-autonomous control of vascular stem cell fate by a cle peptide/receptor system. Proc Natl Acad Sci USA, 2008, 105: 15208-15213

32 Etchells J P, Turner S R. The PXY-CLE41 receptor ligand pair defines a multifunctional pathway that controls the rate and orientation of vascular cell division. Development, 2010, 137: 767-774

33 Hirakawa Y, Kondo Y, Fukuda H. Tdif peptide signaling regulates vascular stem cell proliferation via the WOX4 homeobox gene in Arabidopsis. Plant Cell, 2010, 22: 2618-2629

34 Ji J, Strable J, Shimizu R, et al. WOX4 promotes procambial development. Plant Physiol, 2010, 152: 1346-1356

35 Suer S, Agusti J, Sanchez P, et al. WOX4 imparts auxin responsiveness to cambium cells in Arabidopsis. Plant Cell, 2011, 23: 3247-3259

36 Hedman H, Zhu T Q, von Arnold S, et al. Analysis of the WUSCHEL-RELATED HOMEOBOX gene family in the conifer picea abies 
reveals extensive conservation as well as dynamic patterns. BMC Plant Biol, 2013, 13: 89

37 Sakakibara K, Reisewitz P, Aoyama T, et al. WOX13-like genes are required for reprogramming of leaf and protoplast cells into stem cells in the moss physcomitrella patens. Development, 2014, 141: 1660-1670

38 Ge Y, Liu J, Zeng M, et al. Identification of WOX family genes in Selaginella kraussiana for studies on stem cells and regeneration in lycophytes. Front Plant Sci, 2016, 7: 93

39 Leibfried A, To J P, Busch W, et al. WUSCHEl controls meristem function by direct regulation of cytokinin-inducible response regulators. Nature, 2005, 438: 1172-1175

40 Gordon S P, Chickarmane V S, Ohno C, et al. Multiple feedback loops through cytokinin signaling control stem cell number within the Arabidopsis shoot meristem. Proc Natl Acad Sci USA, 2009, 106: 16529-16534

41 Bartrina I, Otto E, Strnad M, et al. Cytokinin regulates the activity of reproductive meristems, flower organ size, ovule formation, and thus seed yield in Arabidopsis thaliana. Plant Cell, 2011, 23: 69-80

42 Muller B, Sheen J. Cytokinin and auxin interaction in root stem-cell specification during early embryogenesis. Nature, 2008, 453: 1094-1097

43 Kurakawa T, Ueda N, Maekawa M, et al. Direct control of shoot meristem activity by a cytokinin-activating enzyme. Nature, 2007, 445: 652-655

44 Liao C Y, Smet W, Brunoud G, et al. Reporters for sensitive and quantitative measurement of auxin response. Nat Methods, 2015, 12: 207-210

45 de Reuille P B, Bohn-Courseau I, Ljung K, et al. Computer simulations reveal properties of the cell-cell signaling network at the shoot apex in Arabidopsis. Proc Natl Acad Sci USA, 2006, 103: 1627-1632

46 Vernoux T, Brunoud G, Farcot E, et al. The auxin signalling network translates dynamic input into robust patterning at the shoot apex. Mol Syst Biol, 2011, 7: 508

47 Cheng Y, Dai X, Zhao Y. Auxin biosynthesis by the YUCCA flavin monooxygenases controls the formation of floral organs and vascular tissues in Arabidopsis. Genes Dev, 2006, 20: 1790-1799

48 Cheng Y F, Dai X H, Zhao Y D. Auxin synthesized by the YUCCA flavin monooxygenases is essential for embryogenesis and leaf formation in Arabidopsis. Plant Cell, 2007, 19: 2430-2439

49 Yamaguchi N, Wu M F, Winter C M, et al. A molecular framework for auxin-mediated initiation of flower primordia. Dev Cell, 2013, 24: 271-282

50 Skoog F, Miller C O. Chemical regulation of growth and organ formation in plant tissues cultured in vitro. Symp Soc Exp Biol, 1957, 11: 118-130

51 Srikanth A, Schmid M. Regulation of flowering time: All roads lead to rome. Cell Mol Life Sci, 2011, 68: 2013-2037

52 An H L, Roussot C, Suarez-Lopez P, et al. CONSTANS acts in the phloem to regulate a systemic signal that induces photoperiodic flowering of Arabidopsis. Development, 2004, 131: 3615-3626

53 Fornara F, Panigrahi K C S, Gissot L, et al. Arabidopsis DOF transcription factors act redundantly to reduce CONSTANS expression and are essential for a photoperiodic flowering response. Dev Cell, 2009, 17: 75-86

54 Kobayashi Y, Kaya H, Goto K, et al. A pair of related genes with antagonistic roles in mediating flowering signals. Science, 1999, 286: 1960-1962

55 Putterill J, Robson F, Lee K, et al. The constans gene of Arabidopsis promotes flowering and encodes a protein showing similarities to zinc-finger transcription factors. Cell, 1995, 80: 847-857

56 Suarez-Lopez P, Wheatley K, Robson F, et al. CONSTANS mediates between the circadian clock and the control of flowering in Arabidopsis. Nature, 2001, 410: 1116-1120

57 Yamaguchi A, Kobayashi Y, Goto K, et al. TWIN SISTER OF FT (TSF) acts as a floral pathway integrator redundantly with FT. Plant Cell Physiol, 2005, 46: 1175-1189

58 Helliwell C A, Wood C C, Robertson M, et al. The Arabidopsis FLC protein interacts directly in vivo with SOC1 and FT chromatin and is part of a high-molecular-weight protein complex. Plant J, 2006, 46: 183-192

59 Hepworth S R, Valverde F, Ravenscroft D, et al. Antagonistic regulation of flowering-time gene SOC1 by CONSTANS and FLC via separate promoter motifs. EMBO J, 2002, 21: 4327-4337

60 Lee I, Aukerman M J, Gore S L, et al. Isolation of luminidependens-a gene involved in the control of flowering time in Arabidopsis. Plant Cell, 1994, 6: 75-83

61 Michaels S D, Amasino R M. FLOWERING LOCUS C encodes a novel MADS domain protein that acts as a repressor of flowering. Plant Cell, 1999, 11: 949-956

62 Sheldon C C, Burn J E, Perez P P, et al. The FLF MADS box gene: A repressor of flowering in Arabidopsis regulated by vernalization and 
methylation. Plant Cell, 1999, 11: 445-458

63 Iyer-Pascuzzi A S, Jackson T, Cui H C, et al. Cell identity regulators link development and stress responses in the Arabidopsis root. Dev Cell, 2011, 21: 770-782

64 Agrawal G K, Jwa N S, Shibato J, et al. Diverse environmental cues transiently regulate OsOPR1 of the "octadecanoid pathway" revealing its importance in rice defense/stress and development. Biochem Biophys Res Commun, 2003, 310: 1073-1082

65 Habben J E, Bao X M, Bate N J, et al. Transgenic alteration of ethylene biosynthesis increases grain yield in maize under field drought-stress conditions. Plant Biotechnol J, 2014, 12: 685-693

66 Li X Y, Qian Q, Li J Y. The study of mechanism of tiller of rice. Bull Chin Acad Sci, 2003, 4: 274-276 [李学勇, 钱前, 李家洋. 水稻分 蓝的分子机理研究. 中国科学院院刊, 2003, 4: 274-276]

67 Li X, Qian Q, Fu Z, et al. Control of tillering in rice. Nature, 2003, 422: 618-621

68 Jiang L, Liu X, Xiong G, et al. DWARF 53 acts as a repressor of strigolactone signalling in rice. Nature, 2013, 504: 401-405

69 Ashikari M, Sakakibara H, Lin S Y, et al. Cytokinin oxidase regulates rice grain production. Science, 2005, 309: 741-745

70 Li S Y, Zhao B R, Yuan D Y, et al. Rice zinc finger protein DST enhances grain production through controlling Gn1a/OsCKX2 expression. Proc Natl Acad Sci USA, 2013, 110: 3167-3172

71 Sun D. Discussion of ways and measures to improve effective tiller (in Chinese). Agric Dev Equip, 2010, 3: 36-38 [孙丹. 浅谈提高水稻 有效分䒚的途径和措施. 农业开发与装备, 2010, 3: 36-38]

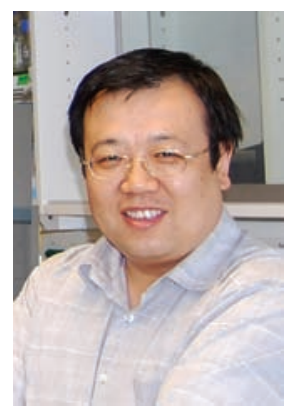

\section{攰忠}

中国科学技术大学生命科学学院教授, 博士生导师. 2011 年入选中国科学院 “百人计划”, 现任中国细胞生物学会植物器官发生分会会长. 1991 和 1994 年 在兰州大学生物系细胞生物学专业获学士、硕士学位. 2003 年在复旦大学获 博士学位. 2003 2005 年赴法国国家科研中心(CNRS)植物分子生物学研究所 (IBMP) 从事博士后研究. 2006 2009 年, 在德国马普发育生物学研究所从事 博士后研究. 2009 2011 年, 在海德堡大学干细胞生物学系工作. 主要研究兴 趣包括: 植物干细胞维持与分化的分子网络, 植物千细胞微环境建立和调控 的分子机理, 以及干细胞调控机制在作物中的转化应用研究. 主要研究成果 发表在 Nature, Nat Cell Biol, Dev Cell, Proc Natl Acad Sci USA 和 Plant Cell 等期刊. 


\title{
Plant development: From cells to individuals
}

\author{
LUO LinJie, ZENG Jian, TIAN ZhaoXia \& ZHAO Zhong \\ School of Life Sciences, University of Science and Technology of China, Hefei 230027, China
}

\begin{abstract}
As the development of research tools in molecular biology, plant developmental biology has been changed its focus from the descriptive analysis of plant morphology to the cellular and gene regulation level. Plants have distinct postembryonic development patterns compare to the animal, which give the plant a flexible developmental plasticity in response to different growth environments. In the long-term of evolution, plants are adapted to the environment changes through the continuous adjustment of their development strategy, which makes the plant world highly diverse. The growth and development of multicellular organisms depend on the maintenance and constant differentiation of stem cells. In plants, most of the organs originate from stem cells where resided in the shoot apical meristem, root apical meristem and cambium. The functional conservation of stem cells in those diverse plants is the basis for ontogenesis. However, from the perspective of evolutionary development, the diversity of key regulatory genes expression in different stem cell populations fulfills the continuous adjustments of development strategy to adapt to environmental changes. The plasticity in stem cell regulations determines the flexibility of plant development, which is conserved in plant kingdom from moss to angiosperms. Of course, the mechanism of stem cell maintenance and differentiation are even more complicated in angiosperms. In model plant of Arabidopsis thanian, the molecular mechanism of stem cell regulations has been extensively studied over the past decades. Multiple signaling molecules and transcription factors are found to tightly control the stem cell fate in Arabidopsis thaliana. The homeodomain transcription factor WUSCHEL (WUS) where expressed in the organizing center (OC) is a key regulator for plant stem cell fate determination. While, stem cells expressed secreted peptide CLV3, negatively regulates the expression of WUS. They form a negative feedback loop that tightly control plant stem cell fate. In addition, the classic phytohormones cytokinin and auxin also play essential roles in the maintenance of stem cells in shoot apical meristem, root apical meristem and cambium, and exhibit complex functional interactions. The molecular organization of the RAM is quite similar to that of the shoot. WOX5 (WUSCHELRELATED HOMEOBOX 5), a homologue of WUS, is expressed in the QC, and induces root stem cell fate in the surrounding cells. The GRAS family transcription factor SHORT-ROOT (SHR) is expressed in the innermost tissue of the root, and SHR moves to the surrounding cell layer activating SCARECROW (SCR), together with PLT1 and PLT2, defines the stem cells fate. In this review, we focused on the functions of plant stem cells in plant postembryonic development, and covered recent findings on plant hormonal regulation in stem cells. We also discussed the integration of endogenous genetic information and external environmental factors in plant development, and how they affected the development of organs, morphology and yield of crops.
\end{abstract}

developmental plasticity, stem cell, plant hormone, pattern formation, yield traits

doi: 10.1360/N972016-00906 